\title{
DETERMINATION OF THE GAS COMPOSITION IN the Pre-Fattening Facility for Piglets
}

\author{
STAJNKO, D.; BERK, P.; Vindis, P. \& LAKOTA, M.
}

Abstract: The effect of vacuum fan on the gaseous composition inside a pre-fattening facility was examined during the growing of seven groups of piglets. The experiment involved measurements of $\mathrm{O}_{2}, \mathrm{CO}_{2}, \mathrm{NH}_{3}$, and $\mathrm{H}_{2} \mathrm{~S}$ concentration at varying airflows $\left(0.18,0.27,0.34,0.47 \mathrm{~ms}^{-1}\right)$ and varying flow rates $(89.77,135.14,168.91$ and 233.49 $\mathrm{m}^{3} \mathrm{~h}^{-1}$ ) inside the barn with $35.96 \mathrm{~m}^{2}$ area and volume of $86 \mathrm{~m}^{3}$ to evaluate compliance with legal exposure limits. The measuring points were located $5 \mathrm{~cm}$ and $66 \mathrm{~cm}$ above the ground in the seven pens and in the service corridor. The humblest gas composition was found $5 \mathrm{~cm}$ above the concrete floor and in the corners with slower airflows, but it was statistically significantly improved with the use of stronger airflow. The installation of the second fan would enable ideal climate, since both fans together could work at lower airflows with less energy consumption. The consistent air ventilation would also reduce animal stress and simultaneously increase the efficiency of feeding.

Key words: pig farm, fan, piglets, gas composition, ammonia
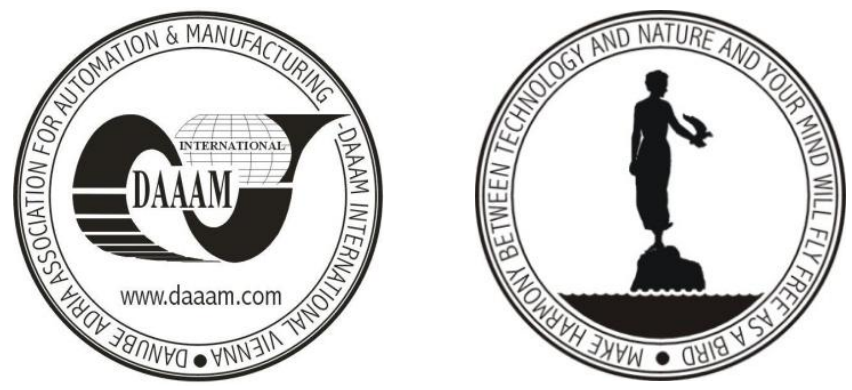

Authors' data: Assoc. Prof. Stajnko, D[enis], M. S. Elect. Eng. Berk, P[eter]; Assist. Prof. Vindis, P[eter], Assoc. Prof. Lakota, M[iran], University of Maribor, Faculty of Agriculture and Life Sciences, Pivola 10, SI-2311, Hoče, Slovenia, denis.stajnko@um.si, peter.vindis@um.si,miran.lakota@um.si.

This Publication has to be referred as: Stajnko, D[enis]; Berk, P[eter]; Vindis, P[eter] \& Lakota, M[iran] (2014). Determination of the Gas Composition in the PreFattening Facility for Piglets, Chapter 14 in DAAAM International Scientific Book 2014, pp.171-180, B. Katalinic (Ed.), Published by DAAAM International, ISBN 978-3-901509-98-8, ISSN 1726-9687, Vienna, Austria

DOI: $10.2507 /$ daaam.scibook.2014.14 
Stajnko, D.; Berk, P.; Vindis, P. \& Lakota, M.: Determination of the Gas Compositi...

\section{Introduction}

Ammonia $\left(\mathrm{NH}_{3}\right)$ is an environmental pollutant (Hartung, 1992; Nielsen et al., 1991; van Breemen et al., 1982) which causes nitrogen enrichment of the soil, and affects groundwater, surface water and the air. This can have hazardous effects on ecosystems. Large amounts of ammonia are usually generated in areas of intensive animal production, such as in North-Western Europe.

Ammonia research at swine facilities started in 1963 in an exploratory phase of study by Day et al. (1965) to investigate gases and odors in two swine finishing buildings. In addition to $\mathrm{CO}_{2}, \mathrm{H}_{2} \mathrm{~S}$, and $\mathrm{CH}_{4}, \mathrm{NH}_{3}$ was detected also in the solid-floor of building that was cleaned daily. Agricultural air quality studies have experienced revolutionary changes in the past three decades, especially after the introduction of advanced analytical instruments and personal computers (Ni et al., 2009). In the mid1980s modern techniques was introduced, which was characterized by gas analysers allowing highly sensitive and continuous $\mathrm{NH}_{3}$ concentration determination, and ventilation control monitoring in Canada (Clark and McQuitty, 1988). In the 1990s, more intensive field investigations were conducted in some European countries (Aarnink et al., 1996). A lot of experiments in Europe included a 6-month continuous field monitoring study in Belgium (Berckmans al., 1998), and a large survey of aerial pollutants within and emissions from 329 livestock buildings in Northern Europe (Wathes et al., 1998).

According to the United States Environmental Protection Agency (USEPA, 2004), $\mathrm{NH}_{3}$ and $\mathrm{H}_{2} \mathrm{~S}$ are the most recognized hazardous gases that are emitted from animal waste. Agricultural $\mathrm{NH}_{3}$ emission is believed to relate to soil acidification, degradation of ecosystems and potential health hazards to humans and animals (Donham et al., 1995). Factors influencing ammonia concentrations and emissions in different swine facilities are mainly affected by barn design, manure storage method, farm management, feed ration and type, animal age and activity, live mass density, outdoor temperature, ventilation design and control, time of day, and season. The main source of ammonia emissions represent wetted pen area with urine. Proportion of wetted floor is influenced with excretory behavior of the pigs, which is associated to the pigs' preferences to the lying pen area (Aarnink et al., 2006).

Ammonia concentrations vary considerably inside swine barns as well as in the barn ventilation exhausts in the range from 0 to $40 \mathrm{ppm}$. Compared with in-house $\mathrm{NH}_{3}$ concentrations among sow, nursery, and finisher houses, the highest values are generally detected in finishing barns (Koerkamp et al., 1998). The typical range of instantaneous $\mathrm{NH}_{3}$ concentrations outside swine barns and in the vicinity of open manure storage facilities is less than $0.5 \mathrm{ppm}$, considerably lower than that of inhouse $\mathrm{NH}_{3}$ concentrations. On the other side, diurnal and seasonal variations usually show higher concentrations at night and in winter, respectively, in barns and at lagoons. Ni et al. (2000) presented data of temporal and spatial $\mathrm{NH}_{3}$ concentration variations inside a finishing barn and its deep pit headspace. Their diurnal patterns were correlated with those of barn ventilation rates, which were relatively low at 
night due to lower outdoor temperatures. Burton and Beauchamp (1986) also showed inverse relationships of inside $\mathrm{NH}_{3}$ concentrations with outdoor temperatures. Over a 1 -year period, February had the highest monthly average concentration of about 21 ppm and August had the lowest of about 6 ppm.

In order to reduce ammonia $\left(\mathrm{NH}_{3}\right)$ emissions the European Union has introduced an emission ceiling for each member state, according to Protocol of Göteborg (CLRTAP, 1999). The ceiling for the Netherlands is assumed to be $128 \mathrm{kt} \mathrm{NH}_{3}$ per year in 2010, which is approximately 40\% less than the emission in 1980 (Sliggers, 2001). In these values pig production is considered responsible for about $38.2 \mathrm{kt}$ per year or $27.5 \%$ of the total ammonia emission from livestock production systems in the Netherlands (RIVM, 2002).

The main purpose of this paper is to represent the gases composition in the piglets fettering facility in Slovenia and compares the data with the latest EU legislative values.

\section{Technical background of measuring gaseous}

The experimental site was a family swine farm located in Vučja vas (NE Slovenia), where the majority of pig farming operations is located. The experiment was conducted in a pre-fattening facility for piglets, which consisted from seven pens in the total area of $35.96 \mathrm{~m}^{2}$ and volume of $86 \mathrm{~m}^{3}$. The on-site waste storage treatment is located just beneath the pens at the normal liquid level. The barn is equipped with one vacuum fan Unitherm $6.3 \mathrm{E}$, which is vertically oriented with the exhaust fans face upwards and four laterally oriented fresh air openings. The piglets were housed in at approximately 4th week and rested for the following 7 weeks, weighing $7-8 \mathrm{~kg}$ upon arrival and gaining an average $0.35 \mathrm{~kg}$ per day.

\begin{tabular}{|l|l|l|l|}
\hline Barn 1 slotted floor & Barn 2 slotted floor & Barn 3 slotted floor & Barn 4 slotted floor \\
\hline Barn 1 solid floor & Barn 2 solid floor & Barn 3 solid floor & Barn 4 solid floor \\
\hline Corridor left & \multicolumn{2}{|c|}{ Corridor centre } & Corridor right \\
\hline \multirow{2}{*}{} & Barn 7 solid floor & Barn 6 solid floor & Barn 5 solidfloor \\
\cline { 2 - 4 } & Barn 7 slotted floor & Barn 6 slotted floor & Barn 5 slotted floor \\
\cline { 2 - 4 }
\end{tabular}

Fig. 1. Experiment layout in the pre-fattening barn

For measuring the effectiveness of the vacuum fan 17 points were selected in different parts of the barn as seen on the Figure 1; two points in each pen, where point 1 was $5 \mathrm{~cm}$ above the bare concrete floor, and point 2 was $5 \mathrm{~cm}$ above the slatted floor. Additional three points were selected $5 \mathrm{~cm}$ above the concrete corridor in the middle of the pen; left, right and just beneath the fan. The second part of the experiment involved the same measuring points in the $66 \mathrm{~cm}$ layer. The measurements were performed during the June and July 2013. A full description of 
Stajnko, D.; Berk, P.; Vindis, P. \& Lakota, M.: Determination of the Gas Compositi... the pig numbers, weights, and number of weeks in rotation for each pen is provided later in Tab. 2.

For measuring the gaseous concentration and environmental data an ECHO analyzer was applied (Ocepek et al. 2011). It contains pulsed fluorescence $\mathrm{H}_{2} \mathrm{~S}_{/} \mathrm{SO}_{2}$ analyzer, $\mathrm{NH}_{3}$ analyzer, which measures ambient ammonia by using the chemiluminescence principle, moisture sensor, thermal sensor, air velocity sensor and pressure sensor. These analyzer draws in sample air at $1.0-1.21 \mathrm{~min}^{-1}$ through an internal vacuum pump. During the field study, zero and span checks for $\mathrm{H}_{2} \mathrm{~S}$ and $\mathrm{NH}_{3}$ concentration were conducted daily.

\section{Gaseous composition during the growing of piglets}

\subsection{Ammonia and carbon dioxide concentrations}

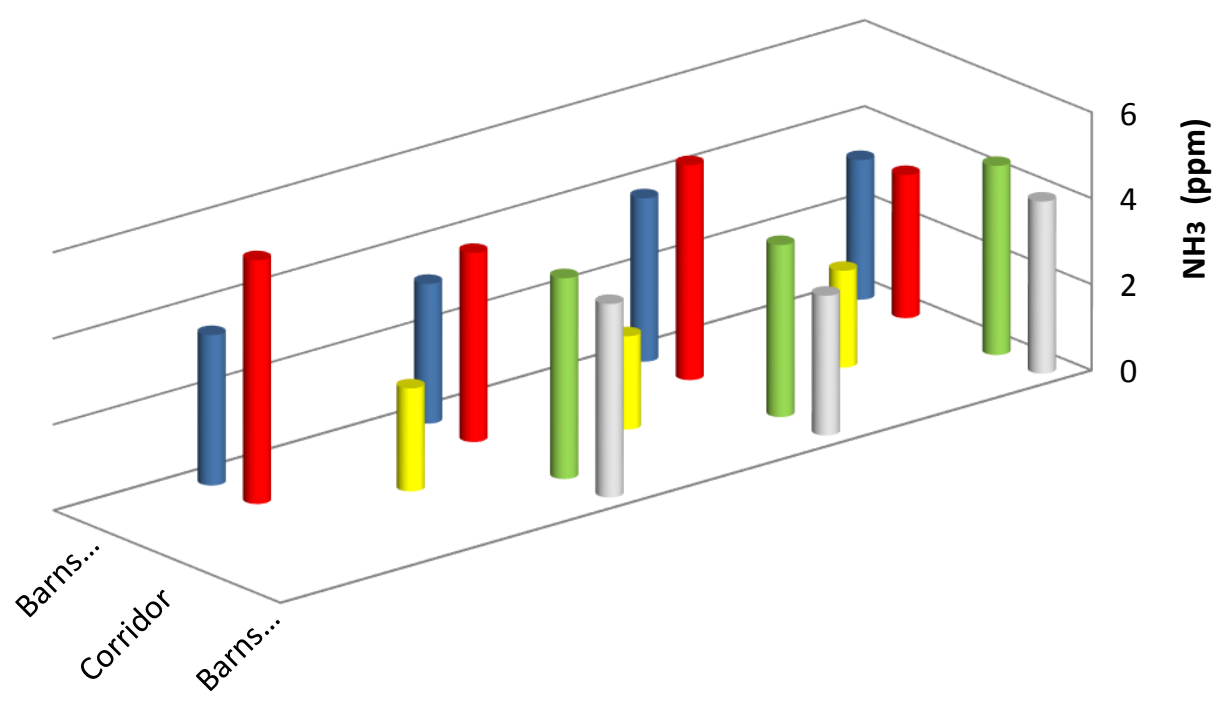

Fig. 2. Distribution of ammonia concentration $\left(\mathrm{NH}_{3}\right)$ in the pre-fattening barn $5 \mathrm{~cm}$ above the floor

In the following chapter we are going to discuss only the ammonia and carbon dioxide concentrations, since there was no significant influence of increasing air flow rates on $\mathrm{O}_{2}$ concentration, temperature, pressure and moisture content. On the other hand, we did not detect any $\mathrm{H}_{2} \mathrm{~S}$ concentration as might be expected from the literature reports.

Figure 2 shows the average concentration of ammonia $\left(\mathrm{NH}_{3}\right)$ in the pre-fattening barn at 17 different points within a measuring period of two months $5 \mathrm{~cm}$ above the floor. As seen the legislative upper limit of $10 \mathrm{ppm} \mathrm{NH}_{3}$ was not exceeded in any part of the barn, which means the air quality was very good. However, still there is a significant higher concentration of $\mathrm{NH}_{3}$ concentration in the corner of pen 1 (5.67 
ppm) and pen 7 (4.67 ppm), because these are the most allocated points in the barn from the fan. The main reason for lower vacuuming effect lies in the vertical walls between the neighboring barns, which prevent the higher airflow. The main reason for installing the walls is i) to prevent the fighting between different groups of piglets from neighboring pens and ii) to prevent the air draft, which is most important threat for respiratory illnesses.

\begin{tabular}{|c|c|c|c|c|c|}
\hline \multirow[b]{2}{*}{ Measuring point } & \multirow{2}{*}{$\begin{array}{l}\text { Average } \\
\text { piglet weight } \\
{[\mathrm{kg}]}\end{array}$} & \multicolumn{2}{|c|}{$\mathrm{NH}_{3}[\mathrm{ppm}]$} & \multicolumn{2}{|c|}{$\mathrm{CO}_{2}[\mathrm{ppm}]$} \\
\hline & & $5 \mathrm{~cm}$ & $60 \mathrm{~cm}$ & $5 \mathrm{~cm}$ & $60 \mathrm{~cm}$ \\
\hline Pen 1 slotted floor & 14.75 & 3.50 & 3.42 & 756 & 685 \\
\hline Pen 1 solid floor & 14.75 & 5.67 & 3.50 & 951 & 784 \\
\hline Pen 2 slotted floor & 15.87 & 3.25 & 2.99 & 707 & 655 \\
\hline Pen 2 solid floor & 15.87 & 4.40 & 3.33 & 878 & 691 \\
\hline Pen 3 slotted floor & 13.84 & 3.80 & 3.60 & 744 & 699 \\
\hline Pen 3 solid floor & 13.84 & 5.00 & 4.20 & 880 & 720 \\
\hline Pen 4 slotted floor & 16.75 & 3.25 & 3.20 & 797 & 701 \\
\hline Pen 4 solid floor & 16.75 & 3.33 & 3.20 & 820 & 802 \\
\hline Corridor left & & 2.25 & 2.16 & 580 & 551 \\
\hline Corridor center & & 2.17 & 2.10 & 410 & 403 \\
\hline Corridor right & & 2.40 & 2.25 & 564 & 480 \\
\hline Pen 5 slotted floor & 21.34 & 4.00 & 3.80 & 976 & 774 \\
\hline Pen 5 solid floor & 21.34 & 4.40 & 3.90 & 1090 & 915 \\
\hline Pen 6 slotted floor & 16.16 & 3.25 & 2.78 & 752 & 691 \\
\hline Pen 6 solid floor & 16.16 & 4.00 & 3.50 & 822 & 758 \\
\hline Pen 7 slotted floor & 14.66 & 4.50 & 3.27 & 810 & 725 \\
\hline Pen 7 solid floor & 14.66 & 4.67 & 3.33 & 895 & 863 \\
\hline
\end{tabular}

Tab. 1. Average $\mathrm{NH}_{3}$ and $\mathrm{CO}_{2}$ concentration 5 and $66 \mathrm{~cm}$ above the floor

Generally the $\mathrm{NH}_{3}$ concentration was significantly higher above the solid floor than above the slotted floor, because in the second case the slurry had been released through the channels and the plug every week, which was sufficient to decrease the ammonia concentrations in this particular part of the pens. This problem was already reported by Aarnink et al., 1996, who detected the higher concentration due to increased urination and defamation on the solid floor. Namely, ammonia is released through the bacterial and enzymatic decomposition of nitrogen compounds contained in the excreta, especially in the urine, which is more accumulated on the solid floor. The higher $\mathrm{NH}_{3}$ concentration in particular pens is also correlated with the average piglets' weight. As seen from Table 2 the finest air was measured at the average piglet weight of $13.84 \mathrm{~kg}$ and the poorest at the average piglet weight of $21.34 \mathrm{~kg}$. According to (Ocepek et al. 2012), such differences in ammonia emission may be explained also as a consequence of change excretory behaviour of the pigs, which is a result of the increased pigs' body weight. 
Stajnko, D.; Berk, P.; Vindis, P. \& Lakota, M.: Determination of the Gas Compositi...

The best effect of the vacuum fan was detected in the corridor where the lowest $\mathrm{NH}_{3}$ concentration $(2.17 \mathrm{ppm})$ was measured in the center point, $(2.25 \mathrm{ppm}$ on the left point and $2.40 \mathrm{ppm}$ on the right point. Slightly higher concentration was detected on the right point due to the uneven distribution of pens (four on one side and three on the other side of the corridor).

As represented in Table 1, the average $\mathrm{NH}_{3}$ concentration was lower in all measuring points $66 \mathrm{~cm}$ above the floor in comparison to $5 \mathrm{~cm}$ height, which confirmed the dilution effect of air mixing caused by the fan. On the other side, this data confirmed the $\mathrm{NH}_{3}$ as a heavy gas once ageing.

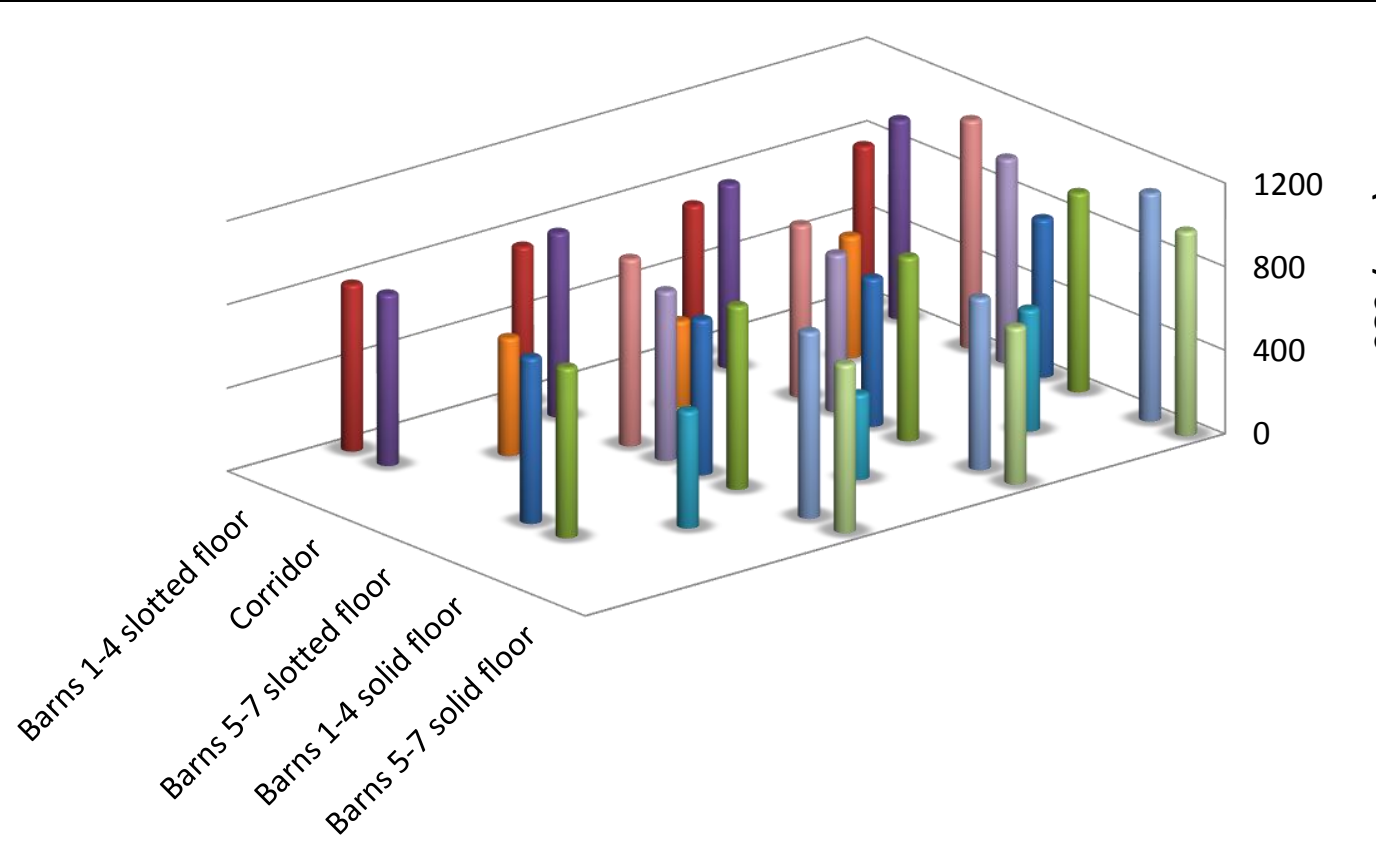

Fig. 3. Distribution of carbon dioxide concentration $\left(\mathrm{CO}_{2}\right)$ in the pre-fattening barn 5 $\mathrm{cm}$ above the floor

Figure 3 shows the average concentration of carbon dioxide concentration $\left(\mathrm{CO}_{2}\right)$ in the pre-fattening barn at 17 different points within a 2 -month measuring period 5 $\mathrm{cm}$ above the floor. Carbon dioxide showed similar spatial distribution as ammonia, so the highest concentration was again measured above the solid floor of pen 5 (1090 ppm), which was most allocated point from the fan. On the average the $\mathrm{CO}_{2}$ concentration was higher on the solid floor than on the slotted floor, because the carbon dioxide is mainly produced by pig respiration and the animals are indeed lying on the solid floor.

Again, the vacuum fan exchanges the air most efficiently in the corridor, where the lowest $\mathrm{CO}_{2}$ concentration (403 ppm) was measured in the center point. Carbon dioxide is mainly produced by pig respiration while ammonia is released through the bacterial and enzymatic decomposition of nitrogen compounds contained in the 
excreta, especially in the urine. Legislative upper limit of $4000 \mathrm{ppm} \mathrm{CO}_{2}$ was not exceeded in any part of the barn for two reasons; i) the vacuum fan was appropriate enough to exchange the inside air with the outside one, ii) the maximal $\mathrm{CO}_{2}$ respiration is limited with the body weight of piglets, which in our case did not exceed $22 \mathrm{~kg}$.

\begin{tabular}{|l|l|l|l|l|l|l|l|}
\hline \multicolumn{2}{|c|}{ Pen 1 } & Pen 2 & Pen 3 & Pen 4 & Pen 5 & Pen 6 & Pen 7 \\
\hline Piglets (number) & 10 & 12 & 12 & 12 & 12 & 12 & 12 \\
\hline Total incoming weight (kg) & 49.5 & 102.5 & 136.5 & 54 & 102.5 & 109.5 & 62.4 \\
\hline Total finishing weight (kg) & 197 & 293 & 299 & 255 & 266.4 & 303.5 & 318.5 \\
\hline Feeding days (day) & 55 & 45 & 45 & 45 & 45 & 45 & 45 \\
\hline Total food intake (kg) & 332.4 & 421.1 & 468.1 & 402.3 & 421.2 & 437.40 & 442.8 \\
\hline Food intake per piglet (g/day) & 755 & 779 & 866 & 745 & 780 & 810 & 820 \\
\hline $\begin{array}{l}\text { Average daily gain per piglet } \\
\text { (g/day) }\end{array}$ & 335 & 352 & 300 & 330 & 349 & 339 & 362 \\
\hline
\end{tabular}

Tab. 2. Daily gain, body weight and feed intake for the piglets in the experiment

\subsection{The influence of varying air flows on the ammonia concentrations}

Figure 4 shows the influence of increasing airflow from 0.18 to $0.47 \mathrm{~ms}^{-1}$ on the average $\mathrm{NH}_{3}$ concentration during the measurements $66 \mathrm{~cm}$ above the floor. As seen, the rising air exchange decreases $\mathrm{NH}_{3}$ concentration significantly. The maximal $\mathrm{NH}_{3}$ concentration $(4.82 \mathrm{ppm})$ was detected at $0.18 \mathrm{~ms}^{-1}$ and minimal $(3.08 \mathrm{ppm})$ at 0.47 $\mathrm{ms}^{-1}$ airflow. On that way the latest suggested EU legislative norm was fulfilled, and subsequently also our hypothesis of sufficient air vacuuming from the barn with one axial fan was proved to be correct. At the airflows 0.34 and $0.47 \mathrm{~ms}^{-1}$ the air circulation was significantly higher than in the first two airflows, thus the $\mathrm{NH}_{3}$ concentration decreased even below $4 \mathrm{ppm}$. However, on the other hand, the maximal air flow rate represents economical hazard, because it does not assure significantly better air quality at higher electricity costs. 
Stajnko, D.; Berk, P.; Vindis, P. \& Lakota, M.: Determination of the Gas Compositi...

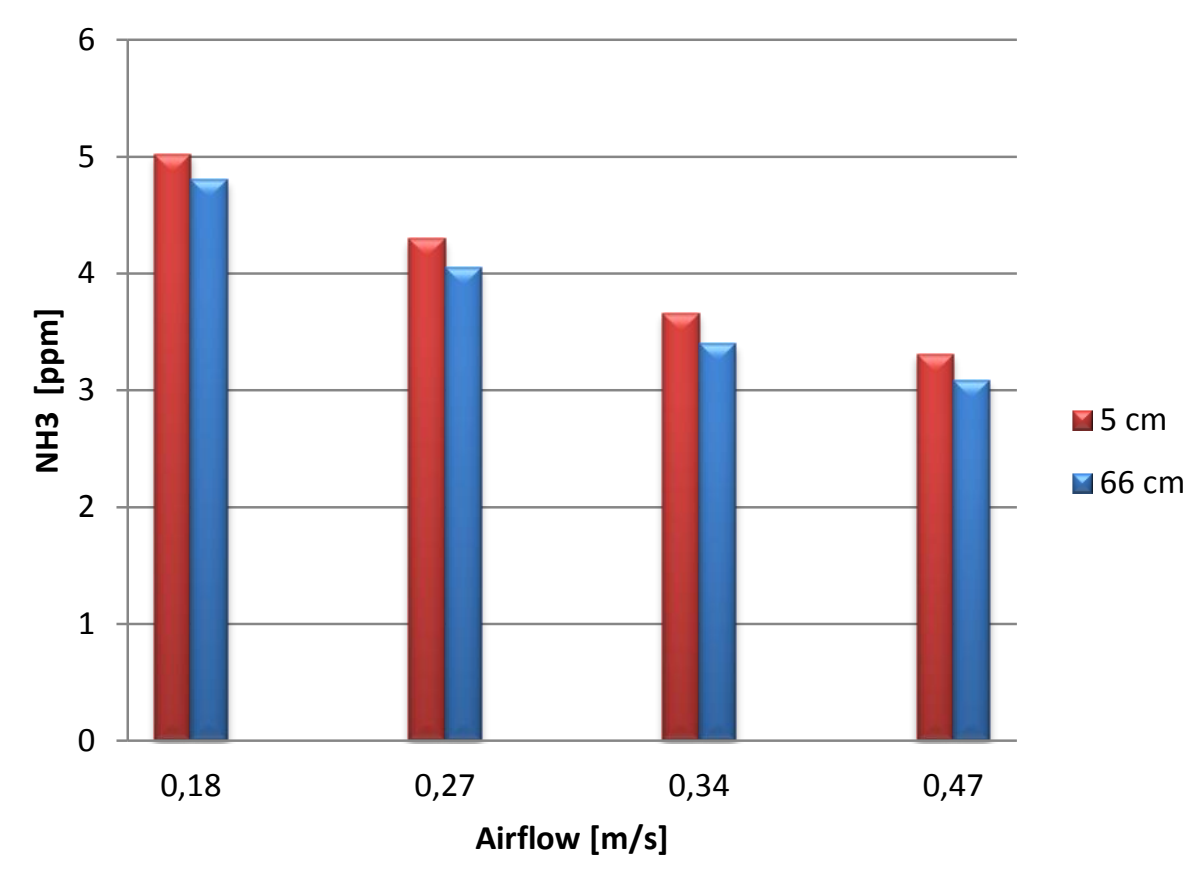

Fig. 4. The average ammonia concentration $\left(\mathrm{NH}_{3}\right)$ at different airflows

\section{Conclusions}

The results of 2-months experiment in the pre-fattening barn showed appropriate microclimate parameters according to the legislative suggestions which were assured with one vacuum Unitherm 6.3E fan. However, the deep inside analysis clearly showed uneven vertical and horizontal spatial distribution of ammonia and carbon dioxide concentration, mainly caused by the vertical full-walls contraction of the pens and the central fen position on the ceiling. The main factors influencing ammonia emission appear to be manure removal and frequency of cleaning of the bard. Regular cleaning of the outside yard seems to be also very important to reduce ammonia emission inside.

When heavier group of piglets was growing in the corner pens, the $\mathrm{NH}_{3}$ and $\mathrm{CO}_{2}$ concentration was significantly higher $5 \mathrm{~cm}$ and $66 \mathrm{~cm}$ above the solid floor then in the middle pens. Beside the higher fodder consumption and excretions production, the main reason represents inefficient air mixing in the corners due to pen's wall made up of whole plates. Thus, the reconstruction of the barn with installation of an additional fan is foreseen as piglets cannot be placed inside the pens made of pipes. On that way the poor air would be exchanged with the fresh one at slower, but constant airflow rate, which would improve the microclimate. Consequently a steady supply of fresh air with more constant temperature would be ensured, which also improve the health status of animals and lower the stress within animals. Therefore, better feed utilization and increase in growth of piglets might be expected. 


\section{Acknowledgements}

The results presented are an integral part of the project CRP V4-1062 entitled "Study of the impact of alternative tillage to improve soil fertility and increase the humus in the soil and reduce $\mathrm{CO}_{2}$ emissions into the atmosphere", which is financed by the Slovenian Research Agency and the Ministry of Agriculture, Forestry and Food of the Republic of Slovenia. The authors also acknowledge the vital contributions made by Matej Osterc and his family for supporting the experiments within his pre-fattening piglet facility.

\section{References}

Aarnink, A.J.A.; Schrama, J.W.; Heetkamp, M.J.W.; Stefanowska, J. \& Huynh, T.T.T. (2006). Temperature and body weight affect fouling of pig pens. Journal of Animal Science, 84, pp. 2224-2231, ISSN 1525-3163

Aarnink, A.J.A.; van den Berg, A.J.; Keen, A.; Hoeksma, P. \& Verstegen, M.W.A. (1996). Effect of slatted floor area on ammonia emission and on the excretory and lying behaviour of growing pigs. Journal of Agricultural Engineering Research 64, pp. 299-310, ISSN: 1095-9246

Berckmans, D.; Vinckier, C.; Hendriks, J.; Ni, J.Q.; Gustin, P.; Urbain, B. \& Ansay, M. (1998). Ammonia Emission and Impact at Pig Farms. Ministry of Middle Classes and Agriculture, Brussels, Belgium

Burton, D.L. \& Beauchamp, E.G. (1986). Nitrogen losses from swine housings. Agricultural Wastes 15, pp. 59-74, ISSN: 0141-4607

Clark, P.C. \& McQuitty, J.B. (1988). Air-quality in farrowing barns. Canadian Agricultural Engineering 30, pp 173-178, ISSN:0045-432X

CLRTAP (1999). Protocol of the 1979 Convention on Long-Range Transboundary Air Pollution: Göteborg Protocol to Abate Acidification, Eutrophication and Groundlevel Ozone: Annex II: Emission Ceilings. United Nation's Economic Commission for Europe (UN/ECE), Göteborg, Sweden Available http://www.unece.org/env//rtap/multi_h1.html, Accessed: 2014-06-17

Day, D.L.; Hansen, E.L. \& Anderson, S. (1965). Gases and odors in confinement swine buildings. Transactions of the ASAE 8, pp. 118-121, ISSN: 0001-2351

Donham, K.J.; Reynolds, S.J.; Whitten, P.; Merchant, J.A.; Burmeister, L .\& Popendorf, W.J. (1995). Respiratory dysfunction in swine production facility workers-dose-response relationships of environmental exposures and pulmonary-function. American Journal of Industrial Medicine 27, pp. 405-418, ISSN: 1097-0274

Hartung, J. A. (1992). General code of practice to reduce ammonia volatilization from animal husbandry. Baltic-Sea-Environment-Proceedings, 44, pp. 38-47, ISSN: 0044-7447 Koerkamp, P.W.G.G.; Metz, J.H.M.; Uenk, G.H.; Phillips, V.R.; Holden, M.R.; Sneath, R.W.; Short, J.L.; White, R.P.; Hartung, J.; Seedorf, J.; Schroder, M.; Linkert, K.H.; Pedersen, S.; Takai, H.; Johnsen, J.O. \& Wathes, C.M. (1998). Concentrations and 
Stajnko, D.; Berk, P.; Vindis, P. \& Lakota, M.: Determination of the Gas Compositi...

emissions of ammonia in livestock buildings in Northern Europe. Journal of Agricultural Engineering Research 70, pp. 79-95, ISSN: 1095-9246

Ni, J.-Q.; Heber, A.J.; Darr, M.J.; Lim, T.-T.; Diehl, C.A. \& Bogan, B.W. (2009). Air quality monitoring and on-site computer system for livestock and poultry environment studies. Transactions of the ASABE 52, pp. 937-947, ISSN: 0001-2351

Ni, J.-Q.; Heber, A.J.; Lim, T.-T.; Diehl, C.A.; Duggirala, R.K.; Haymore, B.L. \& Sutton, A.L. (2000). Ammonia emission from a large mechanically-ventilated swine building during warm weather. Journal of Environmental Quality 29, pp. 751-758, ISSN: 1537-2537 Nielsen, V. C.; Voorburg, J. H. \& Hermite, P. L. (1991). Odour and ammonia emission from livestock farming. Proceedings of a seminar held in Silsoe, UK. Elsevier Applied Science, London, New York, 26-28 March, ISBN: 0203215974

Ocepek, M.; Berk, P.; Janzekovic, M. \& Skorjanc, D. (2011). Use of Echo Monitoring System To Control Environment in Pig Facilities, Chapter 43 in DAAAM International Scientific Book 2011, pp. 535-546, B. Katalinic (Ed.), Published by DAAAM International, ISBN 978-3-901509-84-1, ISSN 1726-9687, Vienna, Austria DOI: 10.2507/daaam.scibook.2011.43

Ocepek, M.; Berk, P.; Rakun, J.; Janzekovic, M. \& Skorjanc, D. (2012). Diurnal Variation of Ammonia Emission in Pig Fattening Facilities, Chapter 10 in DAAAM International Scientific Book 2012, pp. 107-116, B. Katalinic (Ed.), Published by DAAAM International, ISBN 978-3-901509-86-5, ISSN 1726-9687, Vienna, Austria DOI: 10.2507/daaam.scibook.2012.10

RIVM (2002). Het Nederladse milieu verklaard. [Environmental balance 2002. The Dutch environment explained] 170 Kliwer, Alphen aan den Rijn, ISBN: 9014088671.

Sliggers, J. (Ed.) (2001). Towards sustainable levels for health and nature. Publication overview from the theme acidification and large-scale air pollution. Report VROM 010344/h/10-01 17529/ 187, p 229 Netherlands Ministry of Spatial Planning, Housing and the Environment (VROM), The Hague, October

USEPA (2004). National Emission Inventory-Ammonia Emissions from Animal Husbandry Operations. Revised Draft Report. U.S. Environmental Protection Agency, Washington,DC., Available from: http://www.epa.gov/ttnchie1/ap42/ch09/related/nh3inventorydraft_jan2004.pdf, Accessed: 2013-07-24

Van Breemen, N.; Burrough, P. A.; Velthorst, E. J.; Dobben van, H. F.; Toke de Wit; Ridder, T. B. \& Reijnders, H. F. R. (1982). Soil acidification from atmospheric ammonium sulphate in forest canopy throughfall. Nature, 299, pp. 548-550, ISSN: 0028-0836

Wathes, C.M.; Phillips, V.R.; Holden, M.R.; Sneath, R.W.; Short, J.L.; White, R.P.; Hartung, J.; Seedorf, J.; Schroder, M.; Linkert, K.H.; Pedersen, S.; Takai, H.; Johnsen, J.O.; Koerkamp, P.W.G.G.; Uenk, G.H.; Metz, J.H.M.; Hinz, T.; Caspary, V. \& Linke, S. (1998). Emissions of aerial pollutants in livestock buildings in Northern Europe: overview of a multinational project. Journal of Agricultural Engineering Research 70, pp. 3-9, ISSN: $1095-9246$ 